\title{
Scaffolding ESL Tertiary Students' Challenges with Essay Genre: A Systemic Functional Linguistics Perspective
}

\section{Clément Ndoricimpa ${ }^{1 *}$}

\section{* Correspondence: \\ clmentndoricimpa@yahoo.fr \\ Department of English, Maharaja \\ Krishnakumarsinhji Bhavnagar \\ University, Gujarat State, India}

Received: 2 May 2019

Revision: 4 July 2019

Accepted: 28 October 2019

Published online: 20 December 2019

\begin{abstract}
Essay genres are often employed to assess learning at higher education. Students are sometimes required to write essay in examinations and assignments. The expectations of assessors in writing essays are students' ability to present analytical and reasoned arguments and to engage with alternative viewpoints. In fact, in evaluating essays, assessors consider the extent to which a student is able to meet these expectations. However, students may have challenges meeting these expectations and instructors, particularly instructors in the discipline, may not be prepared to provide students with an explicit linguistic description of how these expectations are met. Thus, this study draws from Systemic Functional Linguistics (SFL) to scaffold students' challenges in meeting the expectations of essay genre. In fact, it uses Dreyfus et al's (2010) 3 x 3 linguistic toolkit to analyze essays written by postgraduate students in the department of English at one university in India. The $3 \times 3$ linguistic toolkit is used to zoom in student's challenges in controlling the resources of SFL's three metafunctions (ideational, interpersonal, and textual) at the level of whole text, paragraph, and sentence. After the analysis, the findings revealed that students face challenges controlling the resources of the three modes of meaning at all levels. These challenges include difficulties in grammar, lexical choices, punctuation, following expected organization, answering the question, the use of signposts to create a coherent text, and the use of engagement resources to develop a consistent argument. This study has implications for teaching and assessing academic writing.
\end{abstract}

Keywords: academic writing, argumentative writing, essay genre, second language writing, systemic functional linguistics 


\section{Introduction}

Essay genres are often employed to assess learning at higher education. Students are sometimes required to write essay type examination answer and essay assignments. The expectations of assessors in writing essays can be classified in terms of rhetorical purpose and lexical grammatical features. In terms of rhetorical purpose, an essay is generally organized into three stages: an introduction that states the position of the writer, a body section that presents and develops supporting points to the thesis, and a conclusion that consolidates and reiterates the thesis (Hyland, 1990). In line with these stages, Coffin and Hewings (2003) identify three ways of structuring an essay in terms of three types of rhetorical purpose: exposition, discussion, and challenges. For each type, Coffin and Hewing find different functional stages of an essay. These are the background information, stance taking, detailed sub-arguments, and restatement of the overall position.

In terms of lexicogrammatical features, an essay genre presents linguistic features that describe disciplinary knowledge. According to Woodward-kron (2002), this is accomplished through the process of naming, defining, and taxonomizing. In fact, these linguistic features are related to Systemic Functional Linguistics (SFL) description of ideational meaning. Ideational meaning refers to register variable of field, which presents the nature of disciplinary specific activities, including its knowledge structure. Ideational meaning is concerned with the going on, the happening, the being, the feeling, and the sensing through lexical relation in discourse (Halliday \& Matthiessen, 2004).

Furthermore, the expectations of assessors may include linguistic features that are used to present analytical and reasoned arguments and to engage with alternative viewpoints (Bennett, 2009; Chanock, 2000; Coffin, Hewings \& North, 2012; Deakin \& Lee, 2016; Wingate, 2012). These linguistic elements correspond to those linguistic devices that are used "to analyze and evaluate content knowledge, to position in disciplinary debates, and to articulate that positioning in congruent manner" (Mei, 2006, p.330). In other words, these expectations are related to presenting social relations and therefore "enacting critical thinking" in essays (Nesi \& Gardner, 2006, p.108). In addition, an essay must present linguistic features that are used to signpost connection in written text and therefore to achieve coherence (Hyland, 2009).

However, although these can be reasonable expectations, they are, as Hyland (2016) points out, challenging to meet for many students, particularly L2 students. One reason is that some students may not have been exposed to writing essay genres in their previous schooling, particularly in secondary school. In addition, undergraduate and postgraduate programs may not include academic writing courses on their curriculum and disciplinary teachers may give little attention to teaching academic writing.

\subsection{Statement of the Problem}

Writing essay genre is an integral part of assessing knowledge in many academic disciplines, particularly in the arts, humanities, and social sciences (Hewings, 2010; Moore \& Morton, 2005). Students' success in these disciplines depend on their ability to meet the expectations of assessors. These expectations range from using accurate language to presenting reasoned and critical arguments. However, students face challenges meeting these expectations, particularly L2 students.

In order to understand the seriousness of these challenges, studies that inform teaching practices are conducted. However, these studies follow different perspectives. Some studies focus on grammatical accuracy in students' writing. For instance, the study by Sawalmeh (2013) investigates grammatical errors in written English essays by Arabic-speaking university students. Other studies are concerned with the examination of textual meaning in essays. For example, the studies by Mohammed (2015) and Yang and Sun (2012) investigate the use of linguistic devices to create coherent written texts by university students. Other studies focus on the creation of interpersonal meaning. For instance, the studies by Aull and Lancaster (2014), Deakin and Lee (2019), and Lancaster (2014) examine the use of linguistic resources to present reasoned and critical arguments in successful and less successful students' writing. Although these studies help us understand the challenges that university students face in writing essay genre, they oversimplify the complexities inherent in writing in a given discipline (Woodward-Kron, 2002)

Major findings in these studies reveal that less successful essay contains more grammatical errors, or linguistic features to present reasoned and critical argument in lower frequency, or incorrect use of cohesive devices to create a coherent text. In addition, these studies reveal that successful essay contains less grammatical errors, or high frequency of linguistic features to present reasoned and critical argument, or correct use of cohesive devices. However, these findings do not help us understand the seriousness of the challenges that students face in writing essays genre. They 
only give us a glimpse of, for instance, the number of errors or linguistic features to present reasoned and critical arguments that are found in students' writing. They do not make us understand how those grammatical errors interact with other linguistic features to produce a less successful essay. Deakin and Lee (2016) point out that less successful writing may contain lexical and grammatical realization of reasoned and critical arguments "with other aspects of lowrated texts, such as poor clausal- phrasal- level grammar, vocabulary, content, and organization" (p.22). Therefore, it would be necessary to investigate how grammatical elements interact with other linguistic and non-linguistic elements to produce a written text of low quality or high quality.

In this study, the researcher draws on Systemic Functional Linguistics framework to analyze essay genres written by students during examination at one University in India in order to scaffold the challenges they face producing an essay of high quality. Precisely, the researcher draws on Dreyfus, Humphrey, Mahboob, and Martin (2010)'s 3 x 3, an SFLbased linguistic toolkit developed to help literacy tutors engage analytically with students' writing and make explicit the expectations of academic writing across disciplines.

\subsection{Research Questions}

To meet these objectives, the following research questions were formulated:

1. What difficulties do students in English literature face in writing essay type examination answer as evidenced by a functional analysis?

2. To what extent are students able to produce a written essay of high quality?

\section{Literature Review}

\subsection{Systemic Functional Linguistics}

Systemic Functional Linguistics (SFL) is a theory of language developed by Halliday and his colleagues (Halliday, 1985; Halliday \& Matthiessen, 2004). According to Halliday and Matthiessen (2004), the grammar of language is represented in the form of system networks, not an inventory of structures. A language is a semiotic resource for making meaning, and meaning resides in the systemic patterns of choices. These systemic patterns of choices are divided into three hierarchically interrelated strata (Cheung, 2017). First, there is the expression stratum, which consists of phonology/graphology. This is related to either speech or writing and realizes the second stratum, that of lexicogrammar. The lexicogrammar corresponds to the conceptual level of word, word group, clause and sentence, and it realizes the third stratum, that of discourse semantic. Discourse semantic corresponds to the patterning of largescale textual structure above the sentence- paragraph and larger text. These three strata are related to three modes of meanings, which are in turn associated with three main aspects of context- context of culture and context of situation.

Halliday and Matthiessen (2004) identify these three types of meanings, which are simultaneously created from semiotic resources. They call these meanings metafunctions or trinocular. These modes of meaning include ideational meaning, interpersonal meaning, and textual meaning. According to Martin (2009), these three modes of meaning are linked to three main aspects of context- field, tenor, and mode. Ideational meaning includes resources for building field knowledge, enabling participation in domestic, recreational, academic and professional activities. Interpersonal meaning encompasses resource for valuing these activities and enacting tenor (negotiation of social relations). Textual meaning includes resource for phrasing ideational and interpersonal meaning together in textures sensitive to mode (spoken or written discourses).

These metafunctions provide the basis for analyzing the ways in which semiotic resources are instantiated in texts. Halliday and Matthiessen (2004) point out that the semiotic system of a language is linked to texts through the cline of instantiation. This means that when we study texts we identify patterns of semiotic resources that are used in those texts and link these patterns to the overall semiotic system of a language. However, as Halliday and Matthiessen (2004) argue, texts vary according to the context in which they are used. Martin (2009) points out that context in SFL is modelled through register and genre theory.

\subsection{Register and Genre in SFL}

To realize context in any text, SFL concept of register and genre is important. Register is concerned with a configuration of patterns of instantiation of the overall language system associated with three semiotic functions (Halliday, 1978). These are field, tenor, and mode. Field is concerned with systems of activities; including descriptions of participants, processes, and circumstances (Martin, 1992a). In academic context, field is illustrated by different 
activities in which teachers and students get involved. Tenor in concerned with social relationships between those involved in linguistic act. Martin (2009) argues that these social relationships are enacted through the dimension of power and solidarity. Mode is concerned with the channels of communication (spoken or written) through which we undertake activity (field) and simultaneously enact social relations (tenor). These contextual variables are linked to the three metafunctions.

Genre is another level of context above and beyond tenor, field, and mode (Martin, 1992a). According to Martin (2009), genre refers to social processes, which are related to each other in a text. This has to do with the ways in which field, tenor, and mode are phased together in a text. Therefore, genre is defined as a staged, goal-oriented, purposeful social activity writers/speakers engage as members of a society (Martin, 1986). The idea behind using genre in SFL is that members of a given culture organize meaning at lexical, sentence, and discourse level through multiple stages (Cheung, 2017; Martin, 2009). This means that a text unfolds through stages or phases. For instance, stages in essays unfold as follows: (1) thesis stage, (2) supporting argument stage, and (3) conclusion stage.

\subsection{Related Studies}

Many studies have been conducted within the framework Systemic Functional Linguistics (SFL) to examine the challenges that university students face in writing in a given discipline. Systemic Functional Linguistics framework is used to analyze the challenges students face controlling the linguistic resources used to create ideational, interpersonal, and textual meanings at the level of lexicogrammar and discourse semantic. For instance, the study by Miller, Mitchell and Pessoa (2017) on "L2 student challenges writing argument genre in history studies" revealed that students have difficulties controlling the resources of SFL metafunctions- ideational, interpersonal, and textual- at the level of wholetext, paragraph, and clause/sentence.

In addition, de Oliveira (2011) conducted a study within the framework of Systemic Functional Linguistics to identify the challenges that history students face in writing essays. She compared successful essay and less successful essay. The findings in her study indicated that students faced challenges answering the question, staying on the topic, following expected organization, effectively using academic language, elaborating on their ideas, creating a coherent and cohesive essay, and using interpersonal resources to evaluate and acknowledge alternative views. This means that students have challenges controlling the linguistic resources used to create textual and interpersonal meaning.

Other studies focus on the use of impersonal resources in essays. For instance, the study by Lancaster (2014) on the use of patterns of stance in argumentative essays revealed that less successful assays use few engagement resources to indicate high commitment, critical distance and efforts to build critically discerning readers in the essays. This suggests that less successful students had challenges controlling the resources used to create interpersonal meaning.

\section{Methodology}

\subsection{Context of the Study}

The study was conducted at one University in India in the department of English. This department offers postgraduate course in literature studies. The writing practices in this department follow that of other universities in India. Students are involved in many writing activities, which are designed to help them learn disciplinary ways of demonstrating knowledge through written discourses. Those writing activities include the following. First, students have to write at least one essay assignment for each course on the curriculum. Second, each student has a facebook blog on which he/she posts or uploads written materials, which describe his/her activities in the department or the summary of the novels he/she reads. This activity responds to Indian government's need to use digital technology in learning and teaching. Last, towards the end of each semester, students write four papers for presentation in the classroom.

Therefore, to assess learning in the department of English in all Universities in India, essay genre is used. In fact, students are required to write short essays in examinations to demonstrate their knowledge. These essays are evaluated based on assessment rubric and students' ability to demonstrate critical thinking. The rubric give a clear description of the expectations regarding the quality of the essay. These expectations are categorized into four points: (1) language correctness; (2) integration of external sources; (3) arguments are well justified, there is a logical flow of thoughts from one paragraph to another and the question is properly justified and exemplified; and (4) the handwriting is clear and visible. According to this description, it is clear that the essay that is highly valued is the one, which is free of grammatical errors, which develops clear arguments, which is critical rather than summarizes the plot, which is coherent and which has a clear organization from introduction to conclusion. 
Although these expectations are in line with what scholars suggest (for instance, Bruce, 2016; Deakin \& Lee, 2016), the linguistic resources needed to meet these expectations are not completely specified. In addition, raters' comments on the cover page of the answer books do not provide students with the metalanguage needed to enact a critical argument. Some of these comments include very good, a good analysis, grammatical errors, excellent and very good use of the language, etc. These comments provide an understanding of the challenges that students face in writing essay genres.

\subsection{Design of the Study}

This study followed a qualitative research design. It uses content analysis to examine the challenges that students face in controlling the resources of SFL's three metafunctions- ideational, interpersonal, and textual meanings at the level of whole-text, paragraph, and clause/sentence.

\subsection{Participants}

Participants in this study were 67 students in the department of English at Maharaja Krishnakumarsinhji Bhavnagar University. Among these 67 students, 33 students were in semester 1 and 34 students were in semester three. These students were selected for two reasons. First, they demonstrate learning in examination through essay writing. This means that their success in English literature depends on their ability to meet the expectations of essay genre. Second, they are from different socio-cultural background and therefore they may not have been exposed to academic writing in their previous schooling.

\subsection{Instrument}

To collect the data, one instrument was used. The researcher employed examination essay-type answers. These essaytype answers included essays written by students during examinations. Academic staff in the department of English graded these essays.

\subsection{Data Collection}

Sixty-seven short essays were collected from students' answer books. These essays were written by 67 students in the department of English, among whom 33 students were in semester 1 and 34 students were in semester three. These essays were read in order to understand the challenges students face in meeting the expectations of essays genre. In the result section, the researcher presents the analysis of 4 essays that perfectly represents examples of patterns that were found in the 67 essays.

\subsection{Data Analysis}

A qualitative analysis of the essays was carried out in order to account for students' control of the resources of SFL's trinocular- ideational, interpersonal, and textual. Therefore, the analysis was conducted as follows. First, each essay was analyzed in its entirety and divided into stages. Stage analysis, as Dreyfus et al. (2016) have shown, reveals how meaning is accomplished through organizational patterns. In essay genre, these stages are presented as follows (Table 2).

Table 1. Elements of structure of the argumentative essay

\begin{tabular}{ll}
\hline Stages & Explanations \\
\hline $1 . \quad$ Thesis & $\begin{array}{l}\text { Introduces the proposition to be argued. The } \\
\text { proposition must be related to the question. }\end{array}$ \\
2. Supporting arguments & $\begin{array}{l}\text { Discuss the ground for the thesis. This is } \\
\text { accomplished through sub-arguments and } \\
\text { premises. }\end{array}$ \\
3. Conclusion & $\begin{array}{l}\text { Synthisizes discussion and affirms the validity } \\
\text { of the thesis. }\end{array}$ \\
\hline
\end{tabular}

Based on Hyland (1990).

Second, the researcher drew on 3 x 3 linguistic toolkit developed by Dreyfus, Humphrey, Mahboob, and Martin (2010) (Table 2). Three $\mathrm{x} 3$ linguistic toolkit is a professional learning toolkit designed to help instructors uncover how 
choices from linguistic systems at each level or stratum and from each metafunction realize meaning within a particular academic genre (Dreyfus et al., 2016). Therefore, this provided the researcher with the means to describe each essay by focusing on ideational, interpersonal, and textual meanings of the language. In describing these essays, the researcher considered how these meanings were realized linguistically at the level of the whole text, stages (paragraphs), and sentences, and clauses. This provided the opportunity to scaffold the challenges that students face in writing these essays at the level of the whole text, paragraph, and sentence

Table 2.3 x 3 Framework for analysing essays in literature

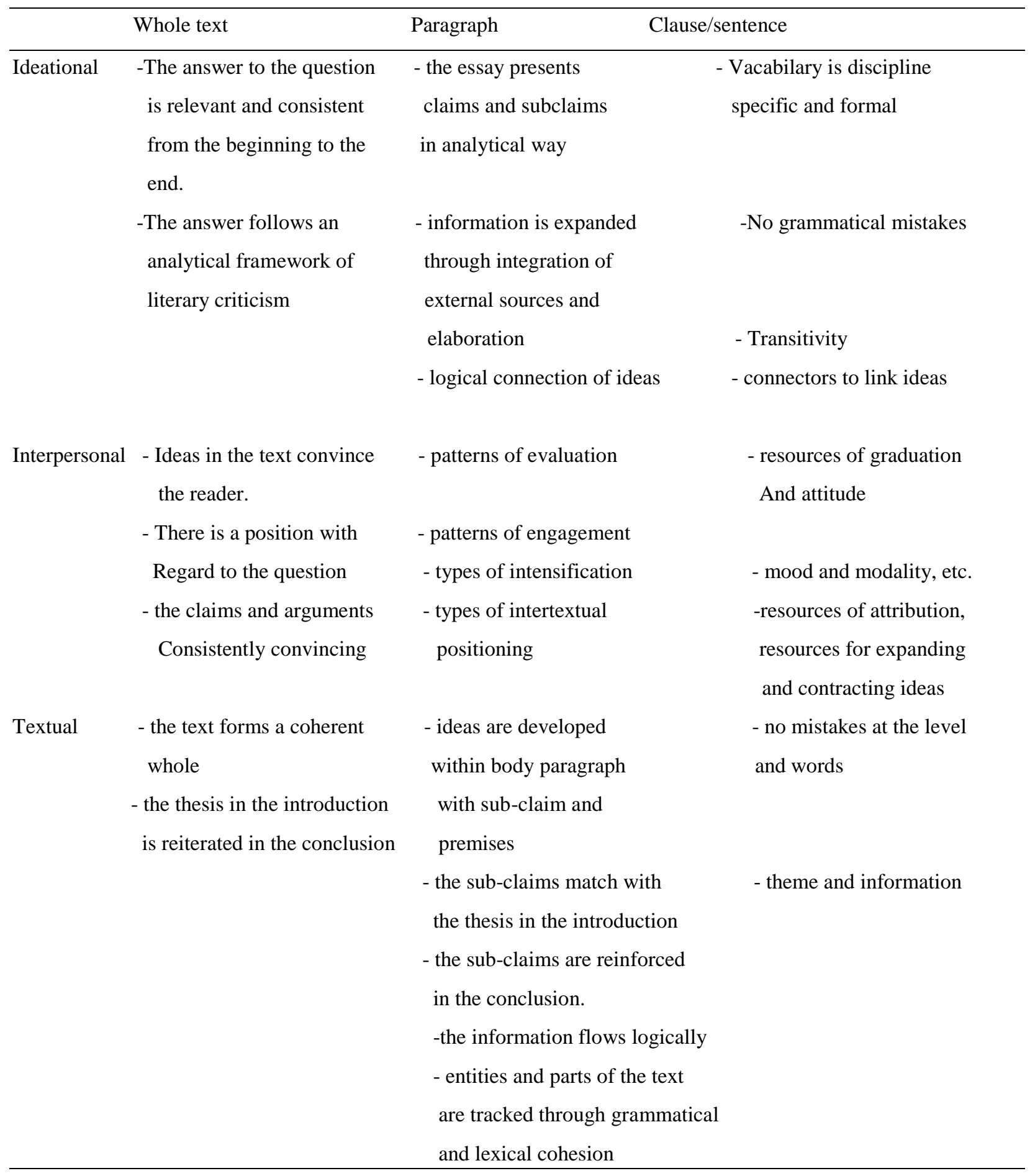


Adapted from Dreyfus et al. (2010) and Miller, Mitchell \& Pessoa (2017). The interpersonal resources were adapted from Martin \& White (2005)

\section{Results}

\subsection{Challenges Controlling the Resources of SFL's Three Modes of Meaning}

\subsubsection{Text 1}

Question: Spiritual degradation and sexual perversion is the central theme of the poem «The Waste Land»

S1. The waste land is a master piece of modern English and also know as a modern epic poem with more than four hundreds lines, in five sections entitled with (1) The Burial of the Dead, (2) A Game of Chess, (3) Fire and Sermon, (4) Death by Water, and (4) What the thunder said.

Before the discussion of present theme of the poem, we have to know about the contemporary condition of the land which Eliot discussed. So, twentieth century was the century of modernist thinkers an era of social, scientific, religious, and political upheavel. For instance, modernist broke the traditional belief and rules and its reason was world war. The world war affects English society in every aspect. Hence, the European country seems as waste land many movement and philosophy like existentialism changed the mind of people.

Spiritual degradation and sexual perversion in the waste land.

S2. As we discussed earlier, world war and philosophy about existence of human change the views of European people. There are many examples in the poem about sexual perversion like King Fisher, typist, and clerk in the game of chess, three daughtes of thames, and also the myth of philomela. So, here Eliot conveys that sexual perversion is the reason of spiritual degradation.

Furthermore, lust throw away people from religion like fisher raped Nun then he was became impotent and his entire land became barren, so he repented and had hope for savior. So, here we can say that sexuality put away people from spirituality. Hence, Eliot put many examples from past to present about sexual perversion and spiritual degradation of the people. He portrayed English society as lustfull society in the poem. One another example of sexual perversion is in the second section 'The game of chess in which typist give herself to the Clerk, his lover for sexual experience.'

Eventually, the poem 'Waste land' is as a satire on English people who go away through spirituality. Though, Eliot somewhere talked sexual perversion is normal if we doing its descent way but he talked that English people take it as temporary pleasure.

S3. To sum up, the theme of sexual perversion and spiritual degradation is a main theme of the poem in which Eliot talked about the English people and their lust degraded spirituality. So Eliot trying to persuade people to avoid this type of lustness through the past and said that the result of lustness is danger of salvation.

\subsubsection{Ideational Meaning}

Text 1 reveals some challenges in controlling the resources of ideational meaning. First, stages are not clearly presented. In the stage 1, the student did not establish a clear thesis (argument) according to the demand of the question. In stage2, subarguments (topic sentences) are not well supported. For instance, the argument, 'lust throw away people from religion' is not well supported by the source text. Therefore, information has not been expanded within paragraph, in terms of general to specific, point to elaboration, evidence to interpretation, and claim to evaluation. In stage 3, the student included something that is not consistent with the question. For example, he stated: «Eliot is trying to persuade people to avoid this type of lust.......). Second, the text contains many errors that affect the meaning of the text. For instance, it contains ill-formed sentences: 'Though, Eliot somewhere talked sexual perversion is normal if we doing its ..........', 'One another examples of sexual perversion in the second section', etc. In addition, it contains collocation errors, spelling errors, punctuation errors. Last, the text contains many logical connectors, but the ideas do not flow logically. Some logical connectors are misused; others are overused. For instance, in stage 1, the student made an overgeneralization error by using 'as' instead of 'as if': "Hence, the European country seems as barren", rather than, "Hence, the European country seems as if it were barren." This provides evidence that the student has difficulties presenting consistent arguments from the beginning to the end stage, logically connected ideas and a text that contains few mistakes. 


\subsubsection{Interpersonal Meaning}

Text 1 exhibits challenges controlling the resources of interpersonal meaning. At the whole text level, the thesis does not answer the question. In fact, the student does not present an argument that is consistent with the prompt. He does not present a clear argument whether 'spiritual degradation and sexual perversion are the main themes of the poem', and does not defend this argument by interpreting and analyzing the source text.

At the paragraph level, the student presents sub-arguments as fact, claims which have to be taken as granted. For instance, "Lust throws away people from religion" is monoglossic in the sense that it does not recognize alternative views. In addition, this argument is not well supported by the source text through analysis and evaluation.

At the sentence and clause level, there is no use of engagement resources to negotiate claims with the reader-raters. In addition, the text contains many subject-verb agreement errors (in S1: e.g. The world war affect....., in S2 : e.g. Eliot put, etc.).

\subsubsection{Textual Meaning}

The text exhibits challenges in controlling textual resources. At the whole text level, arguments are not very well previewed in the introduction. The text starts with background information about the poem, but it does not contain an argument that answers the question. The text is not coherent although it contains logical connectors.

At the level of the paragraph, the topic sentences are not well supported and the information does not flow logically from sentence to sentence. For instance, the first body paragraph starts with "the world war and the philosophy about the existence of human change views of European people". This sentence was followed by "There are many example in the poem about sexual perversion......, "It is clear that the two sentences are not logically related. Therefore, the student does not know how to write a coherent paragraph.

At the sentence and clause level, the paragraphing does not assist information structure and there are punctuation, spelling errors, etc. (e.g.. ... four hundreds lines....., ... many movement ...., ...he was became impotent....., ...going away through spirituality..........so he repent..., ...lustness....).

\subsubsection{Text 2}

Question: Philosophical meaning of the poem 'Stopping by the woods on a snowy evening'

S1. Robert Frost was one of the well-known American writers of the 20th century. Robert frost known as a nature poet. His works deal with themes like nature, personal, and social aspects and human beings in the poems. His popularity is not only in England but all over the world.

'Stopping by woods on snowy evening' poem with deep philosophical meaning in by Frost. It also raises many questions in reader's mind. Why did Frost go into the forest? Why did he want to be lost in the forest?

S2. Snowy means whiteness and purity but this whiteness with darkness. It also brings symbols of darkness. That whiteness is pure but also has aspects of something bad, which is existed with it. So snowy means also dark, gloomy, and sad symbolism.

Evening' means 'old age' that symbolizes the last moments of life. That was the whole day the dark evening will come. Something in our life that was passing through various memories in journey of life, old age' Evening will come at darkest part with sadness. Evening also suggests philosophical meaning that now time of death is near and it can't remove by us.

'The woods are lovely, dark and deep!

While Frost passing through the road, which was between woods and frozen lake, suddenly he stopped there. Frost said that I stopped by woods it means that nature wants the possession of frost. Frost also wants company of Frost.

'The woods are lovely, dark, and deep' in this line Frost uses paradox that lovely and dark means life also with paradox of happiness and sadness of joy and sorrow, both runs parellell one by one, no parmance of it throughout the life.

In this poem, narrator's love for horses and at the same time love for those dark woods attract him more than the world of human being.

'But I have promises to keep, and miles to go before I sleep.' 
This line suggests that Narrator wants to escape from responsblities of life of human world. These responsbilities of family, love/hate, and desires are kept him in attraction of the things. But he wants to go away from all the things, and loves for human beings, love of existence. So philosophical context is also that he knows no more in love of life and existence. This line also indicates that journey of narrator is so long and he wants to complete it before his sleep or death. It also suggests that 'miles to go' means many sufferings and struggles he has to face before long sleep. Without it, his sleep and death will be incomplete so he also wanted to enjoy life, joy, and sorrow of life before his death.

While passing through the forest, there is something attraction in that lovely woods which are dark and sleep that narrator stopped there for a while, he very deeply, and stopped there, he wants die there and wants to loss in the lap of nature and darkness of forest.

« But I have promises to keep » in this line 'I' suggest that Frost himself means all this philosophy of life and journey is his sub-conscious mind. He wants to away from all and wants to live in the lap of nature and lovely woods.

S3. Though all attraction of woods and nature, Frost promises himself that he still wants to go far away before his sleep, after he will satisfactorily enjoy his death, he passes all the sufferings of life and still will face all the problems before the end of his life. Thus this poem with many interpretation and philosophical context emerged as most famous poem of Frost than other poems.

\subsubsection{Ideational and Textual Meaning}

Text 2 reveals some challenges controlling the resources of ideational and textual meaning. At the whole text level, the answer is consistent with the prompt, but the subclaims in the body paragraphs are not previewed in the introduction. For example, in the introduction, the student argues that the poem has deep philosophical meaning, but he does not specify that this philosophical meaning is reflected in the words: woods, snowy, evening, and in some verses of the poem.

At the paragraph level, the topic sentences are not clear. The text does not contain sub-arguments, which are expanded through analysis, interpretation, and evaluation. For instance, the first body paragraph starts with "Snowy means whiteness and purity, but whiteness presents meaning of darkness.» This sentence would act as a topic sentence if it were supported by subclaims from the source text and external sources.

At the sentence and clause level, the text contains many errors. The errors range from punctuation to ill-formed sentences. For instance, in S1, there are incomplete sentence (Robert Frost known as a nature poet), punctuation errors (His popularity is not only in England but all over the world), and capitalization at the beginning of sentence (it also raises many questions...). In S2, there are errors related to preposition, word choices, collocation, ill-formed sentences, etc. (e.g. While Frost passing through the road; Something in our life that was passing through various memories ... ; both runs parellell one by one ; While passing through the forest there is something attraction in that lovely woods which are...). It appears that the student has not yet developed grammatical and lexical features for the presentation of an organized and structured essay.

\subsubsection{Interpersonal Meaning}

Text 2 exhibits some challenges in controlling the resources of interpersonal meaning. At the whole text level, the thesis is not clearly presented and defended through interpretation and analysis of the source text. The student simply states that 'Stopping by the woods on snowy evening' poem has a deep philosophical meaning.' Although this is a clear argument, it does not indicate that the philosophical meaning is reflected in words: woods, snowy, evining, and some verses.

At the paragraph level, patterns of engagement are not used to develop a stance and guide readers towards a preferred position. For instance, in S2, the paragraph starts with a single voiced or monoglossic topic sentence, which assumes that the information is not contested, but the sentence is not supported by the source text and it is ill-formed.

At the sentence and clause level, the text contains subject-verb agreement errors (Evening also suggest...).

\subsubsection{Text 3}

Question: Consider critically Dryden's views on the use of rhyme in drama. 
S1. John Dryden was a poet, essayist critic, and playwright. He was born in 1631 and died in 1700. His age is also called as Dryden's age. His first work was not get success. But his second work was succeed. He wrote 'An essay of dramatic poiessie.' In this essay, he talked about poems and poets.

John Dryden talked about poets and poems of his age. He told that in drama rhyming pattern is very important. It makes it attractive and meaningful. Dryden also talked about four gentlemen's arguments: Crits, Eugenieus, Licidieus, and Neander.

S2. Crits followed ancient form of drama. He told that ancient good rather than modern. He told that modern stands on ancient shoulder. Without ancient, modern can't stand. Ancient followed unities. They strictly followed unity of time, unity of place, and unity of action. Ancients were created of poetics. Their poems have myths.

Euginieus followed the modern form of drama. He told that moderns are very educated. They are very intelligent. So, their poems are very good. Their theme is good rather than ancient. They used rhyme, meters, pan, in their dram and poem, which made them very attractive and very meaningful from other form of drama. Modern is followed by the unity of time, unity of action, and unity of place. But they don't follow as strictly as ancient follow.

John Dryden also followed the modern. Because he was from this age. And his all characteristics match with moderns. So, John Dryden followed modern. He also told that in drama the use of ryme is very important. It makes it different from others.

Licidas followed French drama. French drama didn't follow the unity of time. It has not any act in their drama. They never mixed the form of tragedy and comedy. It use form of drama. It is not devided in any act or scene. So, sometimes it becomes boring drama.

Licidas told that he admired Homes but he loves Shakespeare. In French drama there is only plot that has not any subplots. There are limited characters in drama which are necessary. In this drama, these are not unnecessary and exact characters.

Neander followed modern English drama. This drama, mixed tragedy and comedy. It has been devided into acts and scenes. So, audiences don't bore. There is a plot with subplots in this drama. There are many characters performed in this drama.

S3. John Dryden followed modern drama. Because he was from this age. And in this drama, rhyme is used.

\subsubsection{Ideational and Textual Meaning}

Text 3 presents some challenges in controlling the resources of ideational and textual meaning. At the whole text level, the beginning, the middle, and the end stages of the essay build knowledge, but the knowledge they build is not consistent with the question. For example, the question is to discuss critically Dryden's views on the use of rhyme in drama. However, the student does not present claims and sub-claims in the body paragraphs to answer this question. In addition, the arguments developed in the text are previewed in the introduction and supported in the body paragraph, but they are not reiterated in the conclusion. The arguments developed are not consistent with the demand of the prompt.

At the paragraph level, the topic sentences are clear. The sub-claims are expanded through explanation. However, those sub-claims are not consistent with the demand of the question. For instance, in S2, the student argues that, for instance, Crits follows ancient form of drama; Licidas follows french drama, etc. These arguments are expanded, but they do not answer the question.

At the sentence and clause level, the text contains many errors. The errors include interlanguage errors (e.g. But his second work was succeed, His all characteristics match with moderns), errors related to the use of personal pronouns (e.g. French drama didn't follow the unity of time. It has not any act in their drama.), lexical errors (e.g. He told that ancient good rather than mdern.), the use of adjective in comparison (e.g. Their theme is good rather than ancient.), punctuation errors (e.g. He also told that in drama the use of ryme is very important.), and tenses (Licidas told that he admired Homes but he loves Shakespeare).

\subsubsection{Interpersonal Meaning}

Text 3 exhibits challenges controlling interpersonal resources. At the whole text level, the essay does not really answer the question. Therefore, the claims and arguments developed are not consistently convincing. 
At the paragraph level, engagement resources are not used to construct a critical stance. The student does not include Dryden's views on the use of rhyme in drama and critically analysze these views through the use of attribution (Dryden says that...), concession/counter-expectancy (although, but...), modality (may, could, it seems), endorsement (X shows that ...), and objective metaphor (it is clear that), etc.

At the sentence and clause level, there are errors related to subject- verb agreements (e.g. Their poems has myths, Modern are followed the unity of time, unity of action, ...)

\subsubsection{Text 4}

Question. Can the novel 'Gulliver's Travels' be read as the most powerful attack ever made against man's wickedness and stupidity?'

S1. Jonathan Swift's Gulliver's Travels is and will be remembered for its satirical representation of the neo-classical age. Swift's hatred towards the human follies as well as social evils has made the novel fit for study even after so many years of its publication. The novel is a justification for Swift's own statement: « I heartily hate and detest the animal called man» Indeed it is a powerful attack on man's wickedness and stupidity. Whether it is part 1 of the novel or part 4, from Liliput to the land of Maughnmes, man has been depicted as someone who disrupts the natural order. For Swift; therefore, it seems, Yahoos and Gulliver are the same. Since, the kind of chaos which Gulliver brings to Liliput is quite similar to what the Yahoos brings in the land of Moughnhnms.

S2. The best example of man's stupidity is reflected in part 3, on the island of Liliput. The depiction of scientists involved in stupid experiments without any practical knowledge or common sense creates a perfect picture of man's stupidity. Also, the idea that human knowledge has its boundries and that there are many things to know apart from the one found in books, hints at the prevalent scientific inquiry during the neo-classical age.

Man's wickedness can be traced already in the other three parts. In Liliput, the wickedness leads to war. In Brobdingnag, wickedness leads to illtreatment of outsiders whereas in the land of Moughnhnmes, wickedness leads to complete animalisation behaviour and consequently, a rejection from the ideal society.

Thus, at every step, Gulliver faces one or the other human vices which ultimately leads him to think about the cause of suffering. The statement at the end which springs up is we ourselves are responsible for our suffering.

S3. Hence, the entire novel is supposed to be a medium for the psychological growth of the protagonist who in turn is a representative of the society of his time. The novel is meant to be an attack on the stupidity and wickedness of mankind.

\subsubsection{Ideational and Textual Meaning}

The text presents some challenges in controlling the resources of ideational and textual meaning. At the whole text level, the answer is consistent with the question. However, the argument developed in the text is not very well reinforced in the conclusion.

At the paragraph level, the sub-claims in the body paragraph match with the topic sentence in the introduction. However, the topic sentences are not expanded by integrating relevant content from the source text. For instance, in the second paragraph of S2, the student claims that man's wickedness can be traced already in other three parts. In support of this claim, he says that wickedness leads to war, to ill-treatment of outsiders, and to complete animalization of behaviour. He does not elaborate, interprete, and evaluate these subclaims by integrating information from the source text; for example, information that would explain how wickedness leads to war.

At the sentence and clause level, vocabulary is specific and themes are chosen to predict the topic and the focus of the sentence. For instance, in the sentence: «In Liliput, wickedness leads to war», the students used a marked theme to predict that the focus of the sentence is the location- Liliput. However, the text contains some mistakes. The mistakes include incomplete sentences (e.g. Since, the kind of chaos which Gulliver brings to Liliput is quite similar to what the Yahoos bring in the land of Moughnhnms), punctuation (Indeed it is a powerful attack on man's wickedness and stupidity), and word coinage (animalisation behaviour).

\subsubsection{Interpersonal Meaning}

The text exhibits some challenges in the control of interpersonal resources. At the whole text level, the text has an argumentative thesis framed through pronouncement move (e.g. Indeed, it is a powerful attack on man's wickedness 
and stupidity). This means that the student construes the reader as having the same knowledge. However, the conclusion does not use any interpersonal resources in the conclusion to reinforce this argument.

At the paragraph level, the student does not include or control the external voices to develop his points. He does not use patterns of engagement resource to construct a critical stance. Perhaps more importantly, he does not use attribute move to acknowledge the author of the source text. For example, he frames the topic sentences in S2 through evaluative move (The best example of man's stupidity is reflected in part 3, on the island of Liliput) and entertain move (Man's wickedness can be traced already in the other three parts). However, he does make move to support these arguments with further eveluations or the use of interpersonal resources to justify, reinforce, and acknowledge the source text. In addition, he does not return to these moves of evaluation and entertain in the final sentence to reinforce them.

At the sentence and clause level, the student uses non-modalized verbs (creates, hints, leads). This suggests that the information from the source text is taken as a fact by the student. He does not use objective metaphor (e.g. It is clear that) to interpret the source text and endorsement resources (e.g. This shows that. or Swift demonstrates that...) to indicate that the information from the source text is valid, correct, or undeniable.

\section{Discussion}

The primary objective of this study was to investigate the challenges that students face in writing an essay of high quality. It drew on Systemic Functional Linguistics (SFL) to analyze essay genres written by postgraduate students in English literature. Specifically, it drew on 3 x 3 SFL's linguistic toolkit to scaffold the challenges that students face meeting the expectations of essay genre. In order to meet these objectives, this study addressed the following research questions: (1) what difficulties do students in English literature face in writing essay type examination answer as evidenced by a functional analysis? (2) to what extent are students able to produce a written essay of high quality?

In an attempt to answer the first research question, four essays written by students during examinations were analyzed in order to zoom the challenges that students face controlling the linguistic resources of ideational, interpersonal, and textual meanings. The results obtained indicated that all four essays presented challenges meeting the expectations of essay genre. First, the analysis of the essays demonstrated that the students had difficulties controlling the resources of textual meaning. The essays contained grammatical errors, errors related to lexical choices, punctuations, spelling, subject-verb agreement, the use of logical connectors and ideas did not flow logically. Second, the analysis of the essays showed that students had difficulties controlling the resources of ideational meanings. Some essays (essay 1 and essay 2) did not have clear thesis statement (positioning with regard to the question), and the topic sentences within paragraph were not supported. Other essays (essay 3 and essay 4) did not have consistent argument within paragraphs and reinforcement of arguments in the conclusion. Third, the analysis of the essays also demonstrated that students had difficulties controlling the resources of interpersonal meaning to interpret, justify, reinforce, and acknowledge the source text. The essays did not contain linguistic resources to develop a critical stance from the beginning to the end using engagement resources (expanding resources: entertain and attribute; contracting resources: disclaim, concur, pronounce, and endorse).

These findings are in line with the findings in the study by de Oliveira (2011). Her analysis of history students' essays revealed that students have difficulties in answering the prompt, staying on topic, following expected organization, effectively using academic language, elaborating on their ideas, creating effective coherence and cohesion, and using interpersonal resources to evaluate or acknowledge multiple interpretations of the past. In addition, the findings are in accord with the findings in the study by (Chang \& Schleppegrel, 2011; Lancaster, 2014). In their study, the results revealed that tertiary students, particularly L2 students, have challenges controlling the resources of interpersonal meaning to develop an argument.

In answer to the second research question, the findings revealed that the essays presented elements which affect their quality. The first two essays were of low quality in terms of ideational meaning, textual meaning, and interpersonal meaning. Essay 3 was of low quality in terms of ideational and interpersonal meaning. Essay 4 was of less quality in terms of interpersonal meaning. These findings are in accord with the findings in the study by Pessoa, Mitchell, and Miller (2017). The results in their study indicated the essays presented mixed effectiveness in controlling the resources of ideational, interpersonal, and textual meanings at the level of whole-text, paragraph, and clause/sentence. 


\section{Conclusion}

The essay genre is often employed to assess learning at higher education. Students are sometimes required to write essay type examination answers and essay assignments. The expectations of assessors in writing essays are students' ability to present analytical and reasoned arguments and to engage with alternative viewpoints. In fact, in evaluating essay type examination answers, assessors consider the extent to which a student is able to meet these expectations. Thus, this study uses $3 \times 3$ SFL's linguistic toolkit to scaffold students' challenges meeting the expectation of essay genre with regard to ideational, interpersonal, and textual meanings. It zooms in these challenges at the level of whole text, paragraph, and sentence. The findings revealed that students face challenges controlling the resources of the three modes of meaning at all levels. These challenges include difficulties in grammar, lexical choices, punctuation, following expected organization, answering the question, the use of signposts to create a coherent text, and the use of engagement resources to develop a consistent argument.

Therefore, I recommend instructors to make explicit to students the linguistic expectations of essay genre. Although it may be cumbersome for instructors to provide a detailed account of the resources needed to control the three modes of meaning, they should provide students with an explicit description of how these three modes of meaning are achieved in writing essays or other types of academic writing. This may be accomplished through designing an assessment rubric based on $3 \times 3$ linguistic toolkit. This may also be accomplished through giving students feedback. In addition, they should support students in grammar, basic writing skills, and other language related skills.

\section{References}

Aull, L. L., \& Lancaster, Z. (2014). Linguistic markers of stance in early and advanced academic writing: A corpusbased comparison. Written Communication, 31(2), 151-183. doi: 10.1177/0741088314527055

Bennet, K. (2009). English academic style manuals: a survey. Journal of English for Academic Purposes, 8(1), 43-54. doi:10.1016/j.jeap.2008.12.003

Bruce, I. (2016). Constructing critical stance in university essays in English literature and sociology. Journal of English for Specific Purposes, 42(1), 12-25. http://dx.doi.org/10.1016/j.esp.2015.10.005

Chang, P., \& Schleppegrell, M. (2011). Taking an effective authorial stance in academic writing: Making the linguistic resources explicit for L2 writers in the social sciences. Journal of English for Academic Purposes, 10(3), 140151. https://doi.org/10.1016/j.jeap.2011.05.005

Channock, K. (2000). Comments on essays: do students understand what tutors write? Teaching in Higher Education, 5(1), 95-105. https://doi.org/10.1080/135625100114984

Cheung, L. M. E. (2017). Development of evaluative stance and voice in postgraduate academic writing. A Ph. D thesis: The Hong Kong Polytechnique University.

Coffin, C., \& Hewings, A. (2003). Writing for different disciplines. In C. Coffin, M. J. Curry, S. Goodman, A. Hewings, T. Lillis, \& J. Swann (Eds.), Teaching academic writing: A toolkit for higher education (pp. 4572). London: Routledge

Coffin, C., Hewings, A., \& North, S. (2012). Arguing as an academic purpose: the role of asynchronous conferencing in supporting argumentative dialogue in school and university. Journal of English for Academic purposes, 11(1), 38-51. https://doi.org/10.1016/j.jeap.2011.11.005

Deaking, L., \& Lee, J. J., (2016). Interaction in L1 and L2 undergraduate student writing: Interactional metadiscourse in successful and less-successful argumentative essays. Journal of Second Language Writing, 33(3), 21-34. http://dx.doi.org/10.1016/j.jslw.2016.06.004

De Oliveira, I. C. (2011). Knowing and writing school history: The language of students' expository writing and teachers' expectations. Charlotte, NC: Information age publishing.

Dreyfus at al. (2010). The 3 x 3: Setting up a linguistic toolkit for teaching academic writing. In A. Mahboob \& N.K. Knight (Eds.). Applicable linguistics (PP. 185-199). London: Continuum.

Dreyfus et al. (2016). Genre pedagogy in higher education: The SLATE project. London: Palgrave Macmillan. 
Halliday, M. A. K. (1978). Language as Social Semiotic: The Social Interpretation of Language and Meaning. London: Edward Arnold.

Halliday, M. A. K. (1985). An Introduction to Functional Grammar. London: Edward Arnold (2nd ed). London and Melbourne: Arnold, 1994. 3rd edn (revised by C. M. I. M. Matthiessen), London: Arnold, 2004.

Halliday, M. A. K., \& Matthiessen, C. M. I. M. (2004). An introduction to functional grammar (3rd ed). London: Hodder Arnold.

Halliday, M. A. K. (1990). New ways of meaning: A challenge to applied linguistics. https://eric.ed.gov/?id=ED324960

Hewings, M. (2010). Materials for university essay writing. In N. Hardwood (Ed.), English language teaching materials: Theory and practice. New York: Cambridge university press.

Hyland, K. (1990). A genre description of the argumentative essay. RELC Journal, 21(1), 66-78. doi: $10.1177 / 003368829002100105$

Hyland, K. (2009). Academic discourse. London: Continuum.

Hyland, K. (2016). Writing with attitude: Conveying a stance in academic texts. In E. Hinkel (Ed.), Teaching English grammar to speaker of other languages. New York: Routledge.

Lancaster, Z. (2014). Exploring valued patterns of stance in upper-level student writing in the disciplines. Written Communication, 31(1), 27-57. doi: 10.1177/0741088313515170

Martin, J. R. (1986). Grammaticalising ecology: The politics of baby seals and Kangaroos. Sydney studies in society and culture, 3 .

Martin, J. R. (1992a). English text: System and structure. Amsterdam: Benjamins. Reprinted by Peking University Press, 2004.

Martin, J. R., \& White, P. R. (2005). The language of evaluation: Appraisal in English. New York: Palgrave Macmillan.

Martin, J. R. (2009). Genre and language learning: A social semiotic perspective. Linguistics and Education, 20(1), 10-21. doi:10.1016/j.linged.2009.01.003

Martin, J. R. (2009). Discourse studies. In M. A. K. Halliday \& J. W. Jonathan (eds), Continuum companion to systemic functional linguistics (pp. 154-166). London: Continuum International Publishing group.

Mei, W. S. (2006). Creating a contrastive rhetorical stance: Investigating the strategy of problematization in students' argumentation. RELC journal, 37(3), 329-353. doi: 10.1177/0033688206071316

Miller, R. T., Mitchell, T. D., \& Pessoa, S. (2017). Emergent argument: A functional approach to analysing student challenges with the argument genre. Journal of Second Language Writing, 38(1), 42-55. http://dx.doi.org/10.1016/j.jslw.2017.10.013

Mohammed, A. S. (2015). Conjunctions as cohesive devices in the writings of English as second language learners. Procedia-Social and Behavioral Sciences, 208(5), 74-81. doi: 10.1016/j.sbspro.2015.11.182

Moore, T., \& Morton, J. (2005). Dimensions of differences: A comparison of university writing and IELTS writing. Journal of English for Academic Purposes, 4(1), 43-66. https://doi.org/10.1016/j.jeap.2004.02.001

Nesi, H., \& Gardner, S. (2012). Genres across the disciplines: Student writing in higher education. Cambridge, England: Cambridge University Press.

Pessoa, S. (2017). How SFL and explicit language instruction can enhance the teaching of argumentation in the disciplines. Journal of Second Language Writing, 100(36), 77-78. doi: 10.1016/j.jslw.2017.05.004

Sawalmeh, M. H. M. (2013). Error analysis of written English essays: The case of students of the preparatory year program in Saudi Arabia. English for Specific Purposes World, 14(40), 1-17. https://docplayer.net/67672717Error-analysis-of-written-english-essays-the-case-of-students-of-the-preparatory-year-program-in-saudiarabia.html 
Wingate, U. (2012). Using academic literacies and genre-based models for academic writing instruction: A 'literacy' journey. Journal of English for Academic Purposes, 11(1), 26-37. doi:10.1016/j.jeap.2011.11.006

Woodward-Kron, R. (2002). Critical analysis versus description? Examining the relationship in successful student writing. Journal of English for Academic Purposes, 1(2), 121-143. https://doi.org/10.1016/S14751585(02)00013-9

Yang, W., \& Sun, Y. (2012). The use of cohesive devices in argumentative writing by Chinese EFL learners at different proficiency levels. Linguistics and Education, 23(1), 31-48. doi:10.1016/j.linged.2011.09.004 